\title{
Paediatric ovarian tumours and their associated cancer susceptibility syndromes
}

\author{
Catherine Goudie, ${ }^{1}$ Leora Witkowski, ${ }^{2}$ Stephanie Vairy, ${ }^{3}$ W Glenn McCluggage, ${ }^{4}$ \\ William D Foulkes ${ }^{5}$
}

'Department of Pediatrics, Division of HaematologyOncology, Hospital for Sick Children, University of Toronto, Toronto, Ontario, Canada ${ }^{2}$ Department of Pathology, Brigham \& Women's Hospital, Harvard Medical School, Boston, Massachusetts, USA

${ }^{3}$ Department of Pediatrics, Division of HaematologyOncology, CHU Sainte-Justine, Université de Montréal,

Montreal, Quebec, Canada ${ }^{4}$ Department of Pathology, Belfast Health and Social Care Trust, Belfast, UK

${ }^{5}$ Department of Medical Genetics, McGill University Health Centre, Montreal, Quebec, Canada

Correspondence to Dr William D Foulkes, Department of Medical Genetics, McGill University Health Centre, Montreal, Quebec H4A 3J1, Canada; william.foulkes@mcgill.ca

CG and LW are the co-first authors.

Received 28 July 2017 Revised 26 September 2017 Accepted 28 October 2017 Published Online First 24 November 2017

CrossMark

To cite: Goudie $C$ Witkowski L, Vairy S, et al. J Med Genet 2018:55:1-10.

\section{ABSTRACT}

Non-epithelial ovarian tumours are rare neoplasms that occasionally arise in childhood and adolescence. They can be associated with various cancer susceptibility syndromes. The morphological overlap seen across these tumours and their rarity can make the diagnosis challenging. In the case of an incorrect diagnosis, the underlying genetic susceptibility may be missed. In this review, we outline the genetic background of ovarian non-epithelial tumours arising in children, emphasizing the genes harbouring pathogenic germline variants associated with each tumour type. Specifically, juvenile granulosa cell tumours, Sertoli-Leydig cell tumours, sex cord tumours with annular tubules, Sertoli cell tumours, germ cell tumours and small cell carcinoma of the ovary of hypercalcaemic type are discussed in this review. For each tumour type, we detail the personal and family history features and the presenting characteristics of the ovarian tumour as well as the pathological features and molecular markers that point towards a cancer predisposition syndrome. Throughout, we stress the need for specialised pathological review in difficult cases.

\section{INTRODUCTION}

Ovarian tumours in childhood and adolescence are uncommon and may be associated with cancer predisposition syndromes (CPSs). These tumours are distinguished from those that arise in adulthood by their histological subtypes and by the different CPSs with which they are associated. Clinicians should recognise that an ovarian tumour developing in childhood may be the first sign of a CPS in a family. Diagnosing the CPS offers the important possibility of surveillance for other CPS-related disease in the patient and family.

While many reviews outline the tumours associated with a CPS, very few describe the inverse relationship, that is, when should the clinician suspect a CPS following the diagnosis of an ovarian neoplasm. Here we discuss ovarian tumours that are most likely to arise in childhood and their associated CPSs. We also discuss clinical features that may indicate a higher likelihood of a CPS and cover current screening recommendations for these tumours. It is important to note that the most prevalent ovarian neoplasm associated with a CPS occurs in adults with predisposing BRCA1/BRCA2 mutations: high-grade serous carcinoma. However, these are epithelial neoplasms and are exceedingly rare in individuals under age 18 years. Mucinous epithelial neoplasms do occur under age 18 years but are not known to be associated with cancer susceptibility syndromes. Most paediatric ovarian tumours which are associated with a CPS are in the non-epithelial categories.

\section{SEX CORD-STROMAL TUMOURS (SCST) Juvenile granulosa cell tumour \\ General aspects}

Juvenile granulosa cell tumours (JGCTs) (figure 1A) are rare ovarian tumours, accounting for less than $1 \%$ of ovarian neoplasms but accounting for approximately two-thirds of SCSTs presenting in childhood. ${ }^{12}$ Just under one-half of JGCTs are diagnosed in the first decade of life and an additional one-third in the second decade. ${ }^{1}$ Over $95 \%$ of patients present with disease limited to the ovary and these low-stage patients have an excellent prognosis, with $>90 \%$ overall survival with surgical resection alone. ${ }^{3}$ Most tumours are unilateral, although $2 \%-5 \%$ of cases are bilateral. ${ }^{12} \mathrm{~A}$ common presenting feature of JGCTs is isosexual precocious pseudopuberty, as these tumours often secrete oestrogen. ${ }^{3}$ Rarely they are associated with androgenic manifestations.

\section{Key differential diagnoses}

The differential diagnosis of JGCT includes other SCSTs and small cell carcinoma of the ovary of hypercalcaemic type (SCCOHT). The SCSTs which are most likely to be morphologically confused with JGCT are adult granulosa cell tumour (AGCT) (figure 1B) and Sertoli-Leydig cell tumour (SLCT) (figure 1C), although occasionally others may enter into the differential diagnosis. Immunohistochemistry (using markers such as inhibin, CD56, FOXL2, steroidogenic factor-1 and calretinin) is useful in diagnosing a SCST but not in distinguishing between the various types (figure 1D). From a molecular viewpoint, somatic hotspot missense FOXL2 mutations (c.402C>G; p.C134W) are found in approximately $95 \%$ of AGCTs, which are extremely rare in children, while the mutation is hardly ever reported in other SCSTs, including JGCT. Therefore, in cases where the differential includes AGCT and JGCT, demonstration of the presence or absence of a FOXL2 mutation may be extremely useful. ${ }^{45}$ Patients with SCCOHT may have hypercalcaemia and do not exhibit features of precocious pseudopuberty or other hormonal manifestations. Immunohistochemistry is useful in distinguishing between JGCT and SCCOHT since the former is usually inhibin positive and the latter 


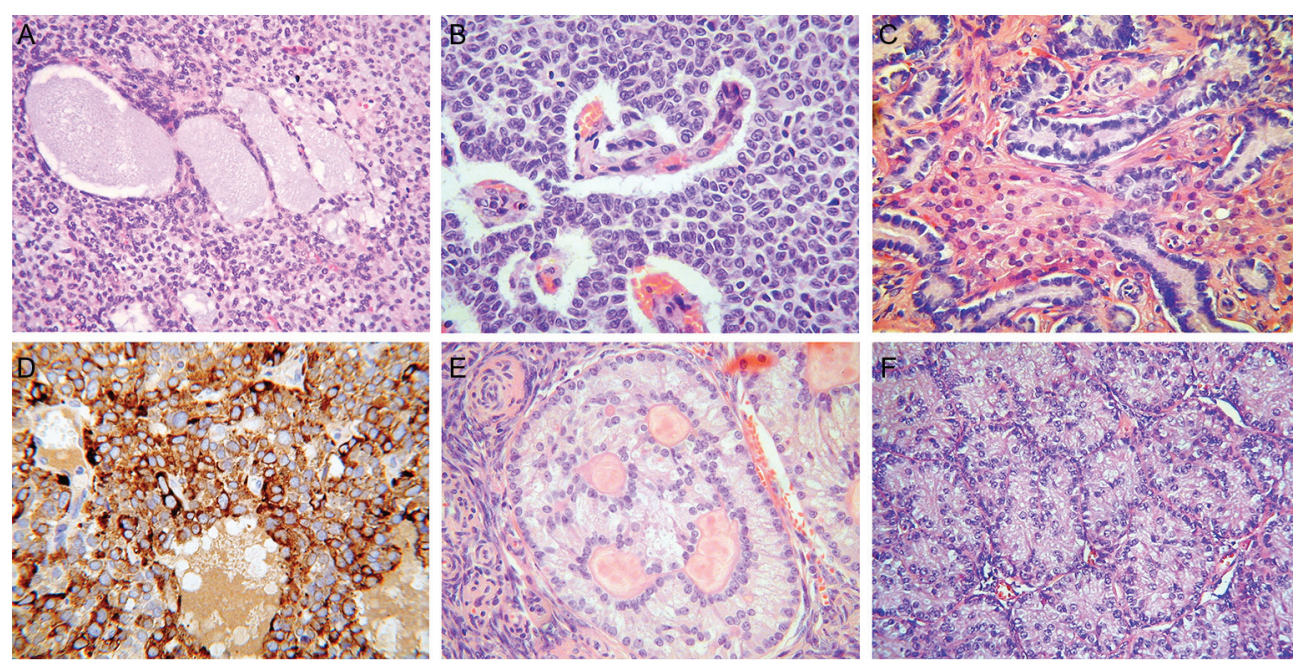

Figure 1 Various morphological types of ovarian SCST. These may exhibit considerable morphological overlap and expert pathology review may be required for a correct diagnosis. (A) Ovarian JGCT with diffuse arrangement of cells and larger follicle-like structures containing basophilic material. (B) Ovarian adult granulosa cell tumour composed of diffuse and microfollicular arrangements of tumour cells with bland vesicular nuclei. (C) Ovarian well differentiated Sertoli-Leydig cell tumour composed of Sertoli cell tubules with intervening Leydig cells with abundant eosinophilic cytoplasm. (D) JGCT which is diffusely positive with inhibin; this is a useful marker of ovarian SCSTs but does not allow distinction between the various types. (E) Ovarian sex cord tumour with annular tubules showing characteristic 'punched-out' spaces containing hyaline material. (F) Ovarian Sertoli cell tumour composed of solid Sertoli cell tubules. JGCT, juvenile granulosa cell tumour; SCST, sex cord-stromal tumour.

negative. As discussed later, almost all SCCOHT lack expression of SMARCA4 (figure 2), while there is positive nuclear staining of JGCTs with this marker.

\section{Cancer predisposition syndromes}

JGCTs have been described in association with Ollier disease and Maffucci syndrome, subtypes of enchondromatosis syndromes (table 1). Tamimi and colleagues reported the first case of an ovarian JGCT in a 15 -year-old girl with Ollier disease. ${ }^{6}$ Since then, 11 cases have been reported in the English literature. ${ }^{7}$ Ollier disease (OMIM \#166000) and Maffucci syndrome (OMIM \#614569) are skeletal disorders secondary to a dysplastic mesodermal process affecting the metaphyseal region of the short and long tubular bones. Although they are both types of non-spinal enchondromatosis, Maffucci syndrome includes soft tissue haemangiomas, while Ollier disease does not. ${ }^{8}$ They are considered non-hereditary disorders characterised by the presence of multiple enchondromas with asymmetric distribution with an estimated prevalence of $1 / 100000 .^{9}$ Somatic mutations in the IDH1 and IDH2 genes, classically affecting Arg132 of IDH1 or Arg172 of IDH2, have been identified in enchondromas and haemangiomas in patients with Ollier disease and
Maffucci syndrome and have been linked to histone hypermethylation. ${ }^{8} 10$ A similar somatic mutation in these two genes has been suggested to explain the occurrence of JGCT, but this has yet to be confirmed. ${ }^{1011}$

Enchondromas that occur in Ollier disease and Maffucci syndrome become clinically apparent at a very young age and have the potential to transform into chondrosarcoma in up to $40 \%$ of patients. ${ }^{12}$ Following enchondromas, haemangiomas and chondrosarcoma, JGCT is considered the most common tumour in patients with Ollier disease or Maffucci syndrome. Most patients have had a diagnosis of enchondromatosis prior to the occurrence of the JGCT. Interestingly, many reports have described the ovarian tumour to be located ipsilaterally to the predominant skeletal dysplasia. ${ }^{13}$ As the long bones of the skeleton and the gonads are both derived from the mesoderm, some authors have hypothesised that involvement of the ovary is a manifestation of a generalised mesodermal dysplasia process. ${ }^{13}$

Other CPSs have occasionally been reported in patients with JGCT. Plon and colleagues described a child with a JGCT who had a germline mutation in PTEN and TP53. ${ }^{14}$ DICER1 somatic hotspot mutations have occasionally been identified in JGCTs, and two cases of JGCT have been associated with DICER1
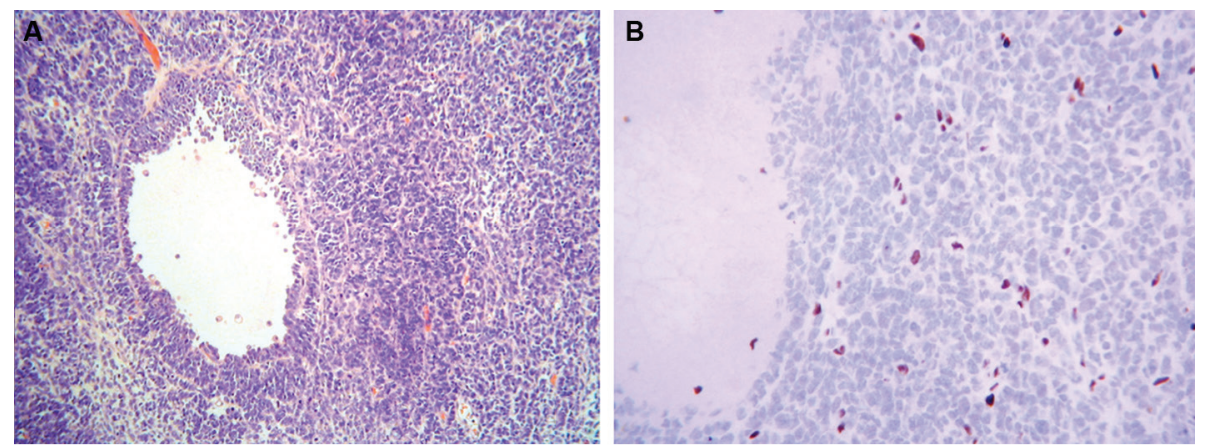

Figure 2 (A) Small-cell carcinoma of the ovary of hypercalcaemic type composed of small round blue cells with scant cytoplasm and with follicle-like formations. (B) There is loss of nuclear staining with SMARCA4 (BRG1) with a positive internal control in the form of staining of endothelial cells. 
Table 1 Features of paediatric ovarian tumours and their associated syndromes

\begin{tabular}{|c|c|c|c|c|c|}
\hline Ovarian tumour & $\begin{array}{l}\text { Common age } \\
\text { of onset }\end{array}$ & Related CPS (gene) & $\begin{array}{l}\% \text { of cases associated } \\
\text { with a CPS* }\end{array}$ & $\begin{array}{l}\text { Features that increase the likelihood } \\
\text { of a CPS }\end{array}$ & Other CPS-related tumours \\
\hline $\begin{array}{l}\text { Juvenile } \\
\text { granulosa cell } \\
\text { tumour }\end{array}$ & $6-13$ & $\begin{array}{l}\text { Ollier diseaset } \\
\text { Maffucci syndromet }\end{array}$ & Low & $\begin{array}{l}\text { P: Enchondromas (bony protuberances, } \\
\text { skeletal angular deformities), } \\
\text { haemangiomas } \\
\text { F: N/A } \\
\text { T: Unknown }\end{array}$ & $\begin{array}{l}\text { Chondrosarcoma, brain } \\
\text { tumours (glioma) }\end{array}$ \\
\hline $\begin{array}{l}\text { Sex cord tumour } \\
\text { with annular } \\
\text { tubules }\end{array}$ & $10-30$ & $\begin{array}{l}\text { Peutz-Jeghers syndrome (STK11) } \\
25 \% \text { de novo }\end{array}$ & $\begin{array}{l}\text { High: } \\
30 \%-35 \%\end{array}$ & $\begin{array}{l}\text { P: Younger age of onset, GI polyps, } \\
\text { mucocutaneous hyperpigmented macules } \\
\text { F: GI polyps, colorectal/gonadal/breast } \\
\text { cancer, mucocutaneous hyperpigmented } \\
\text { macules, large calcifying Sertoli tumours } \\
\text { in males } \\
\text { T: Bilateral, multifocal, small/microscopic } \\
\text { tumours, microcalcifications }\end{array}$ & $\begin{array}{l}\text { Mucinous ovarian and } \\
\text { fallopian tube neoplasms } \\
\text { and minimal deviation } \\
\text { adenocarcinoma, Gl polyps, } \\
\text { colorectal cancer, cervical } \\
\text { cancer, breast cancer, } \\
\text { pancreatic carcinoma }\end{array}$ \\
\hline Sertoli cell tumour & $20-30$ & $\begin{array}{l}\text { Peutz-Jeghers syndrome (STK11) } \\
25 \% \text { de novo }\end{array}$ & Low & $\begin{array}{l}\text { P: Younger age of onset, GI polyps, } \\
\text { mucocutaneous hyperpigmented macules } \\
\text { F: GI polyps, colorectal/gonadal/breast } \\
\text { cancer, mucocutaneous hyperpigmented } \\
\text { macules, large calcifying Sertoli tumours } \\
\text { in males } \\
\text { T: Sertoli tumour of oxyphilic and lipid-rich } \\
\text { subtypes }\end{array}$ & \\
\hline
\end{tabular}

\begin{tabular}{|c|c|c|c|c|c|}
\hline Gonadoblastoma & $15-19$ & 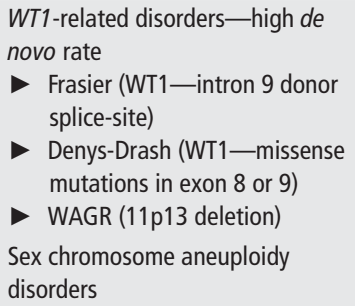 & Moderate & $\begin{array}{l}\text { P: Genitourinary tract structural } \\
\text { malformations, aniridia, Wilms tumour, } \\
\text { gonadal dysgenesis, renal parenchymal } \\
\text { disease (FSGS or mesangial sclerosis) } \\
\text { F: Wilms tumour, end stage renal failure/ } \\
\text { dialysis in young relative } \\
\text { T: Bilateral tumours }\end{array}$ & $\begin{array}{l}\text { Wilms tumour } \neq \text {, early onset } \\
\text { progressive nephropathy } \\
\text { (Frasier=focal and segmental } \\
\text { glomerular sclerosis; Denys- } \\
\text { Drash=mesangial sclerosis) }\end{array}$ \\
\hline $\begin{array}{l}\text { Sertoli-Leydig cell } \\
\text { tumour }\end{array}$ & $15-30$ & DICER1 syndrome (DICER1) & High: $>50 \%$ & $\begin{array}{l}\text { P+F: DICER1-associated neoplasms, } \\
\text { younger age of onset } \\
\text { T: Bilateral tumours }\end{array}$ & $\begin{array}{l}\text { MNG, PPB, ERMS (cervical/ } \\
\text { ovarian), cystic nephroma, } \\
\text { CBME, DTC, ASK, } \\
\text { pineoblastoma, NCMH, PitB }\end{array}$ \\
\hline SCCOHT & $18-35$ & $\begin{array}{l}\text { RTPS2 (SMARCA4) } \\
\text { Low de novo rate }\end{array}$ & High: $>30 \%$ & $\begin{array}{l}\text { P: Young age of onset } \\
\text { F: SCCOHT }\end{array}$ & $\begin{array}{l}\text { Rhabdoid tumour (ATRT and } \\
\text { extracranial MRT) }\end{array}$ \\
\hline
\end{tabular}

*Low: <1\%, Moderate: 1\%-25\%, High: >25\%.

IIDH1 and IDH2 somatic mosaic mutations described in enchondromas and haemangiomas of these patients.

¥Bilateral Wilms tumour and stromal-predominant histology increase the likelihood of a WT1 germline variant.

ASK, anaplastic sarcoma of the kidney; ATRT, atypical teratoid rhabdoid tumour; CBME, ciliary body medulloepithelioma; CPS, cancer predisposition syndrome; DTC, differentiated thyroid carcinoma; ERMS, embryonal rhabdomyosarcoma; F, family; FSGS, focal segmental glomerular sclerosis; GI, gastrointestinal; MNG, multinodular goitre; MRT, malignant rhabdoid tumour; P: patient; PitB, pituitary blastoma; PPB, pleuropulmonary blastoma; RTPS2, rhabdoid predisposition syndrome type 2; SCCOHT, small cell carcinoma of the ovary of hypercalcaemic type.

syndrome, ${ }^{15}$ but a definitive link between JGCT and DICER1 mutations requires a larger series of cases. As DICER1 mutations are common in ovarian SLCT, it is possible that those JGCTs with the mutation represent misdiagnosed SLCTs; as discussed there may be morphological overlap between the two tumour types and JGCT-like areas may be seen in SLCTs. ${ }^{11}$ The study of additional cases of JGCT associated with DICER1 mutations, with expert pathological review to confirm the diagnosis, is required given these previous reports. ${ }^{15}$ Similar comments pertain to gynandroblastoma, a rare mixed ovarian SCST often exhibiting areas of both JGCT and SLCT; rarely these have been shown to contain DICER1 mutations and it is possible that some of these represent misdiagnosed SLCTs with JGCT-like areas.

As only a handful of cases of JGCT have been reported in the context of enchondromatosis syndromes and the link between other CPSs is not established, we have very little evidence on which to base genetic counselling recommendations. However, physical examination in patients with JGCT should include evaluation for features of enchondromatosis (table 1). Equally, there are no standardised management strategies for ovarian tumour surveillance in enchondromatosis syndromes. Although there are no consensus guidelines, we recommend that regular follow-up of growth and pubertal developmental be part of the surveillance for JGCTs in females with Ollier disease or Maffucci syndrome. As JGCTs are rare and characteristically benign, it seems reasonable not to incorporate specific ovarian imaging surveillance in enchondromatosis syndromes, unless clinically indicated.

\section{Sertoli-Leydig cell tumours (SLCTs) \\ General aspects}

SLCTs are an uncommon SCST, comprising 1\%-2\% of paediatric ovarian cancers. ${ }^{16}$ In a majority of cases, they are unilateral and confined to the ovary. They have been reported in females between the ages of 2 and 75, but most commonly occur in the second and third decades of life. ${ }^{17}$ SLCTs are composed of Sertoli and Leydig cells in varying proportions; according to the 2014 WHO Classification, they are categorised into well, moderately and poorly differentiated forms. ${ }^{18}$ Heterologous elements (including mucinous epithelium, rhabdomyoblastic and 
Box Challenges in the pathological diagnosis of ovarian tumours in the context of CPS

- An individual pathologist may never encounter certain cancer predisposition syndrome (CPS)-related ovarian neoplasms (most of which are non-epithelial) throughout their career due to their rarity.

- Morphological overlap among ovarian sex cord-stromal tumours (SCSTs) may lead to 'picture-matching' and a potentially incorrect diagnosis. This can result in inappropriate management and a missed association with a CPS.

- Expert pathology review and specific immunohistochemical markers or molecular testing may be required for correct diagnoses, especially in the paediatric population.

- While immunohistochemical markers are useful in diagnosing an ovarian SCST, they are of little or no value in distinguishing between the morphological types.

- When uncommon tumours are assigned to a CPS, journal editors and reviewers must ensure, as far as possible, that the pathological description is adequate and accurate.

cartilaginous stromal elements, foci of carcinoid tumour) and/or a retiform pattern may be seen in moderately and poorly differentiated variants. ${ }^{18}$

Patients often present with hormonal manifestations, especially androgenic (leading to features of virilisation) and more uncommonly oestrogenic, including precocious puberty and menstrual abnormalities. ${ }^{17}$ Retiform tumours often develop at a younger age and are less associated with endocrine manifestations. ${ }^{19}$ The degree of differentiation of SLCTs has been shown to correlate with the patient's prognosis, with well-differentiated forms almost always behaving in a benign fashion while poorly differentiated variants often exhibit malignant behaviour. ${ }^{17}$

Key differential diagnoses

SLCTs often result in diagnostic difficulties for pathologists in part because of their rarity and because they have a wide differential diagnosis (box). There may be considerable morphological overlap with other SCSTs and, as discussed, immunohistochemistry is of little or no value in distinguishing between the various SCSTs (figure 1D). However, immunohistochemistry is useful to distinguish SLCT from endometrioid carcinoma with which it may occasionally be confused. Similarly, retiform SLCTs may be confused morphologically with serous epithelial neoplasms but the latter occur at a much older age and the immunophenotype is different.

\section{Cancer predisposition syndromes}

SLCTs often manifest in the context of DICER1 syndrome (OMIM \#601200), which is characterised by germline mutations in the DICER1 gene. In addition to SLCT, patients with this syndrome are at risk for developing very specific, typically rare paediatric neoplasms as well as more common neoplasms in adulthood (table 1, figure 3A).

Patients with DICER1 syndrome typically have a loss of function germline mutation in DICER1 that can occur anywhere along the gene, along with a somatic missense DICER1 mutation
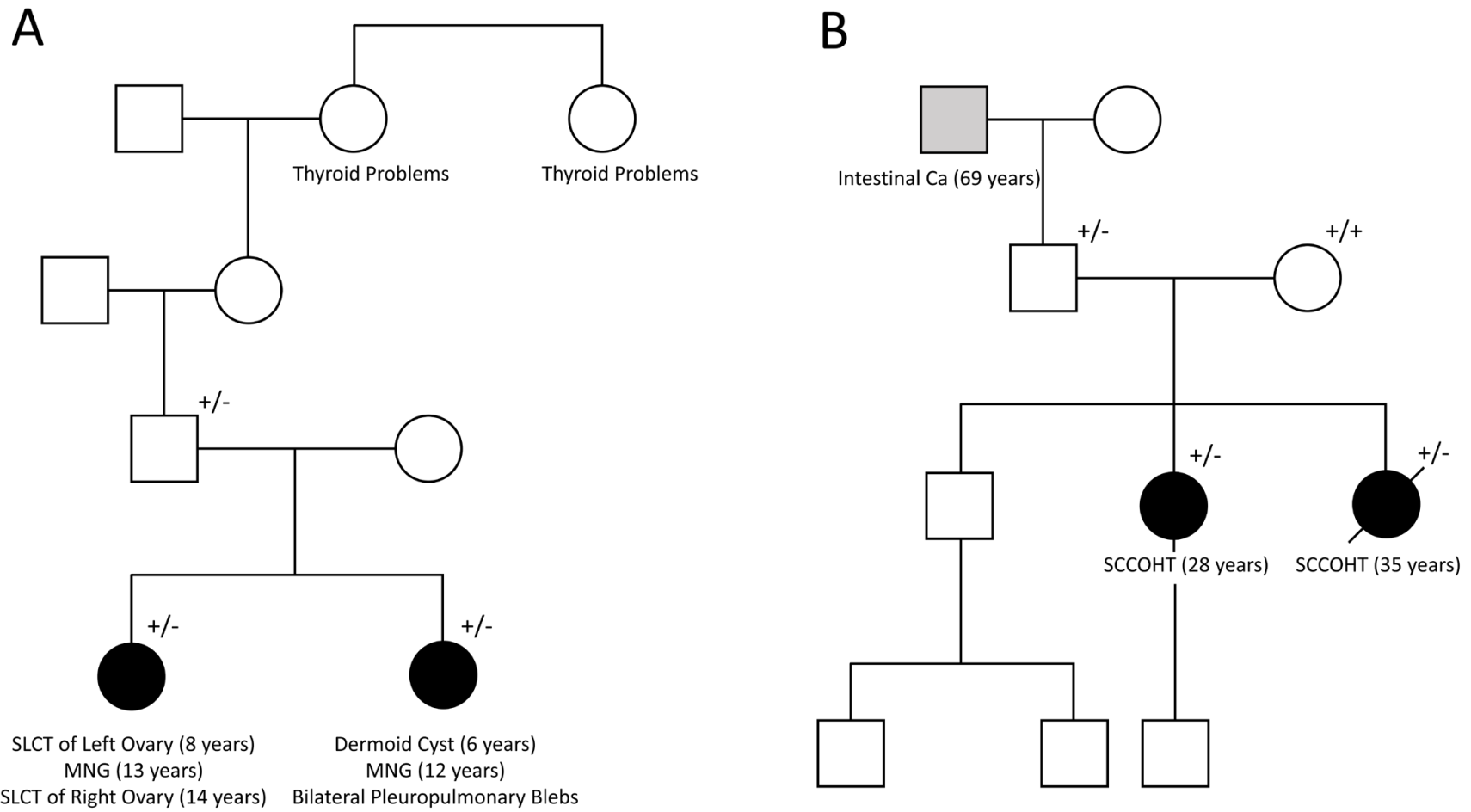

Figure 3 Pedigrees of families with manifestations of DICER1 syndrome and RTPS2. (A) Family with DICER1 syndrome-related manifestations. Affected relatives had a germline DICER1 variant: c. 1525C>T (p.Arg509X). (B) Two sisters with SCCOHT who inherited a germline deletion of the entire SMARCA4 gene from their unaffected father. Black=affected, White=unaffected. $+/+=$ wild type, $+/==$ heterozygous for pathogenic variant. MNG, multinodular goitre; RTPS2, rhabdoid predisposition syndrome type 2; SCCOHT, small cell carcinoma of the ovary of hypercalcaemic type; SLCT, Sertoli-Leydig cell tumour. 
in trans, most often in the RNAse IIIb 'hotspot' region. ${ }^{20}{ }^{21}$ In non-hereditary cases of DICER1-related tumours, patients have two somatic mutations in DICER1 with no germline mutation. SLCTs are by far the most common gynaecological manifestation of the DICER1 syndrome and a recent study showed that $100 \%$ of moderately and poorly differentiated SLCTs contain either germline or somatic DICER1 mutations. ${ }^{22}$ Conversely, this same study suggested that well-differentiated SLCTs are not associated with germline or somatic DICER1 mutations. ${ }^{22}$ However, the number of well-differentiated SLCTs was small and currently we recommend that all patients with SLCT should be referred to a genetics service for consideration of DICER1 testing. This study also showed that moderately and poorly differentiated SLCTs without DICER1 mutations were misclassified neoplasms of some other tumour type, reinforcing the necessity for accurate pathology diagnosis (box).

In patients with SLCT, the presence of either bilateral tumours (a very rare phenomenon), a young age of onset or a personal or family history of a DICER1-related neoplasm should raise suspicion for a genetic cause. ${ }^{23} 24$ While the presence of a germline DICER1 mutation does not currently have an impact on treatment or survival, it is important for clinical follow-up of the patient as well as for surveillance and education for other at-risk family members. For affected individuals and parents of younger girls with DICER1 mutations, recognising the presenting clinical signs of SLCTs may be beneficial. Parents of patients with germline mutations may be unaffected due to either the low penetrance of DICER1 mutations in the parent or a de novo variant in the patient. For patients with DICER1-related ovarian tumours, consensus recommendations from the 2016 American Association for Cancer Research Childhood Cancer Predisposition Workshop have recently been published. ${ }^{25}$ For more information on DICER1 syndrome, visit http://www.dicer1syndrome.ca.

Additionally, SLCTs have been seen in young women and children with Peutz-Jeghers syndrome (PJS; see next section for details on PJS). ${ }^{26} 27$ However, a definitive link between SLCT and PJS requires further study.

\section{Sex cord tumour with annular tubules (SCTAT) General aspects}

Ovarian SCTAT is a rare neoplasm, representing approximately $1 \%-2 \%$ of ovarian SCSTs. ${ }^{28} 29$ They have been reported in females aged between 5 and 57 years, with slightly less than half presenting at $\leq 18$ years. ${ }^{30} 31$ Most tumours are confined to the ovary, are rarely associated with hormonal manifestations and follow a benign course. ${ }^{30} 31$ While most of the time SCTAT is not associated with a genetic syndrome, in 30\%-35\% of cases it occurs in the setting of PJS. The non-syndromic cases are usually unilateral, large and symptomatic. They may exhibit malignant behaviour with spread beyond the ovary. Those associated with PJS typically occur in younger patients (mean age 28 years versus 34 years in non-syndromic cases) and are often an incidental microscopic finding in ovaries removed in females known to have this syndrome. ${ }^{31}$ They are typically small, bilateral and multiple and clinically benign, although a small proportion exhibit malignant behaviour with extraovarian spread.

\section{Key differential diagnoses}

The morphological features of SCTAT are characteristic and the diagnosis is often straightforward (figure 1E), although given the rarity of the neoplasm, many pathologists will never encounter a case. ${ }^{31}$ The differential diagnosis chiefly includes other SCSTs, especially AGCT, SCT and SLCT. However, the rare gonadoblastoma, a mixed germ-cell and SCST may also enter into the differential diagnosis. ${ }^{31}$

\section{Cancer predisposition syndromes}

There is a well-recognised association between SCTAT and PJS. ${ }^{28} 31$ PJS is an autosomal dominant condition characterised by mucocutaneous melanocytic lesions, gastrointestinal hamartomatous polyps and the development of various benign and malignant neoplasms (table 1). The pigmented macules arise in the first few years of life in $90 \%$ of individuals; these may however fade with age. Approximately one-third of patients with PJS have symptoms related to gastrointestinal polyps by age 10 and two-thirds by age $20 .^{32}$ The mean age of onset of ovarian tumours, particularly SCTAT (mean 28 years old), is lower than that of all other PJS-related cancers. ${ }^{33}$ Patients with PJS may also develop other gynaecological neoplasms such as other ovarian SCSTs, non-HPV-related cervical adenocarcinomas (gastrictype) and mucinous neoplasms at various sites such as the ovary. Males with PJS can also develop testicular large-cell calcifying Sertoli cell tumours.

A germline mutation in the tumour suppressor gene STK11 (also called LKB1) is the underlying cause of PJS in approximately $80 \%-90 \%$ of clinically affected families, without significant variation among racial and ethnic groups. ${ }^{34}$ Almost half of affected individuals have no family history compatible with PJS and the de novo mutation rate is estimated to be $25 \%$, demonstrating the value of genetic testing for diagnosis. ${ }^{35}$ More than 300 causative variants in the STK11 gene have been reported, the majority of which are loss of function, although missense variants and partial or whole gene deletions have been described. ${ }^{36}$ Somatically, loss of heterozygosity at $19 \mathrm{p} 13.1$ is seen in the SCTATs of patients with PJS. ${ }^{37}$ A handful of studies have attempted to describe genotype-phenotype correlations with conflicting results. ${ }^{38-40}$

The precise lifetime risk for a female carrier of an STK11 germline mutation to develop a SCTAT is unknown but likely underestimated as they are often small and asymptomatic. ${ }^{41}$ The cumulative risk of developing an ovarian tumour in a STK11 germline mutation carrier is approximately $20 \%$ between the age of 15 and 64 years, with SCTAT accounting for a majority of the ovarian tumours. ${ }^{3142}$

When a diagnosis of an ovarian SCTAT is made, clinicians should pay attention to aspects of the personal history, family history and tumour characteristics, which could suggest the presence of PJS (table 1). Considering the rarity of this ovarian tumour and its specific association with PJS, we recommend sending all children with SCTAT for a formal genetic evaluation and testing for a germline STK11 mutation. Currently, no specific recommendations exist for surveillance for gonadal tumours in children with PJS. One group suggests starting yearly surveillance at age 25 with pelvic examination, pap smear and transvaginal ultrasound. ${ }^{33}$ This surveillance is not specific to SCTAT, but is used for all gynaecological cancers. Nevertheless, a female carrier of PJS should be examined at least yearly with special attention paid to symptoms and signs which may suggest hormonal changes. ${ }^{43}$

\section{Sertoli cell tumours}

\section{General aspects}

Sertoli cell tumours account for $<5 \%$ of ovarian SCSTs and predominantly present in women of reproductive age (mean 30 years). ${ }^{44}$ In a series of 54 patients (age range 2-76 years) reported by Oliva and colleagues, $14 \%$ of patients were prepubertal. $^{44}$ These tumours commonly result in hormonal 
manifestations, especially oestrogenic and less commonly androgenic or progestogenic. ${ }^{19}{ }^{44}$ Sertoli cell tumours (figure $1 \mathrm{~F}$ are most often benign neoplasms confined to the ovary and have an excellent prognosis with low reported rates of recurrence. ${ }^{45}$ Rare lipid-rich and oxyphilic subtypes of Sertoli cell tumour have been reported..$^{45}$

\section{Key differential diagnoses}

Ovarian Sertoli cell tumours may have a wide differential diagnosis which can include other SCSTs (SLCT, AGCT, SCTATs), endometrioid carcinoma, carcinoid tumour and various metastatic adenocarcinomas. ${ }^{4}$ A correct diagnosis and distinction from the other neoplasms in the differential may be facilitated by a panel of immunohistochemical markers.

\section{Cancer predisposition syndromes}

Sertoli cell tumours, particularly the lipid-rich and oxyphilic subtypes, have been described in children and young women with PJS. ${ }^{47}$ In the series of Oliva and colleagues, $6 / 54$ patients with Sertoli cell tumours were reported to have PJS, of which lipid-rich and oxyphilic subtypes were predominant. ${ }^{44}$ In another report of 16 SCSTs from patients with PJS, four were lipid-rich and two were oxyphilic Sertoli cell tumours, with most of these SCSTs arising in the first two decades of life (range 4-30 years). ${ }^{27}$ Conversely, in a study by Tavassoli and Norris of 28 patients with ovarian Sertoli cell tumour (age range 7-79 years), four had lipid-rich variants and none had signs of PJS ${ }^{45}$ In males with PJS, oestrogen-producing testicular Sertoli cell tumours have been reported. ${ }^{48}$

When a diagnosis of a Sertoli cell tumour is made, clinicians should be aware of certain aspects of the personal history, family history and tumour characteristics (such as lipid-rich or oxyphilic subtypes) that raise the possibility of PJS (table 1). It seems reasonable to send a child with an ovarian Sertoli cell tumour for genetic counselling and testing for STK11 mutations only if the clinician has a higher suspicion based on additional features.

\section{GERM CELL TUMOURS}

\section{General aspects}

Malignant germ cell tumours comprise $75 \%$ of ovarian neoplasms arising in the first 20 years of life and account for $15 \%$ of malignancies in adolescents aged 15-19 years old. ${ }^{47}$

Ovarian germ cell tumours are a heterogeneous group of neoplasms arising from pluripotent primordial germ cells, including teratoma (mature and immature), choriocarcinoma, yolk sac tumour (YST; also called endodermal sinus tumour), dysgerminoma, embryonal carcinoma and mixed subtypes. Teratomas (the majority of which are mature) are the most common ovarian germ cell tumours, followed by dysgerminoma and YST. $^{49}$ Gonadoblastoma is a mixed germ cell-SCST with Y-chromosome material that characteristically develops in the context of gonadal dysgenesis. Although considered benign, gonadoblastomas have the potential to evolve into a dysgerminoma and exhibit malignant behaviour. ${ }^{5051}$

Ovarian germ cell tumours most frequently present with a palpable mass and abdominal pain, and approximately $10 \%$ can present with an acute abdomen as a result of ovarian torsion, haemorrhage or rupture. ${ }^{52}$ Certain subtypes may be associated with an elevated serum $\beta$ HCG or alpha-fetoprotein $(\alpha \mathrm{FP}) .{ }^{53}$ Malignant germ cell tumours are highly curable, with 89\%-98\% survival rates. ${ }^{49}$ Adverse prognostic factors include advanced tumour stage and elevated serum markers. ${ }^{5455}$

\section{Key differential diagnoses}

The differential diagnosis depends on the morphological subtype of germ cell tumour. Mature teratomas (dermoid cysts) are usually easily diagnosed. The differential diagnosis of some of the other morphological subtypes mayinclude a wide range of non-germ cell neoplasms. A variety of immunohistochemical markers, including $\alpha \mathrm{FP}$, placental alkaline phosphatase, OCT3/4 and SALL4, may assist in diagnosis.

\section{Cancer predisposition syndromes}

Increasing evidence supports a genetic predisposition to the development of germ cell tumours. Genetic syndromes and multiple sex-chromosome aneuploidy syndromes leading to various degrees of gonadal dysgenesis have been consistently associated with germ cell tumour development, particularly but not limited to gonadoblastoma.

WT1-related disorders, most commonly Frasier syndrome and Denys-Drash syndrome (DDS), are described in association with ovarian gonadoblastoma. Both diseases are associated with steroid-resistant progressive nephropathy, gonadal tumours and male pseudohermaphrodism and therefore may easily be missed when the patient is phenotypically female ${ }^{56}$ The WT1 gene is a tumour suppressor gene that encodes a zinc finger transcription factor involved in regulation of early gonadal and kidney development. ${ }^{5758}$ It consists of 10 exons, with two regions of alternative splicing in exons 5 and 9. The final nucleotide of exon 9 codes for lysine, threonine and serine (KTS) and a correct ratio of KTS is necessary for the normal function of this gene.

Frasier syndrome is typically caused by a point mutation on the donor splice-site mutation in WT1 on intron 9, leading to a decrease in +KTS isoforms. ${ }^{59}$ It results in a slowly progressive glomerulopathy leading to nephrotic syndrome often in the first decade of life and typically resulting in renal failure in the second or third decade. ${ }^{60} 61$ These patients have gonadal dysgenesis with streak gonads, which are associated with a high risk of gonadoblastoma. The frequency of unilateral or bilateral gonadoblastoma in these patients is reported to be between $37 \%$ and $60 \% .{ }^{60} 6263$ Patients with Frasier syndrome who developed dysgerminoma have been described, some of these tumours having a gonadoblastoma component. ${ }^{63}{ }^{64}$ Gonadal tumours are reported in $67 \%$ of type 1 (female XY) and $37.5 \%$ of type 2 (male XY), but not in type 3 (female XX) Frasier syndrome. ${ }^{60}$

DDS results from a germline missense mutation in WT1 exons 8 or 9 that code for zinc fingers 2 or 3 , leading to abnormal production of the WT1 protein. ${ }^{65}$ Most cases of DDS are caused by one of two missense mutations located in exon 9: c.1180C $>\mathrm{T}$ (p.Arg394Trp) or c.1186G >A (p.Asp396Asn). ${ }^{65} 66$ This results in early-onset nephrotic syndrome andprogression to renal failure, male pseudohermaphrodism and development of Wilms tumour. ${ }^{56}$ Wilms tumours are the most frequent malignancies seen in patients with DDS. Unilateral or bilateral gonadoblastomas are described in patients with DDS, classically presenting in children between age 1.3 and 2.6 years. ${ }^{67}$ In a series of 150 patients with DDS, the frequency of gonadoblastoma was reported to be $4 \% .{ }^{56}$ Gonadoblastoma, Wilms tumour and renal parenchymal disease tend to develop early, with an average age of presentation of 1.7 years for tumours and 1.4 years for the renal manifestations. ${ }^{56}$

WAGR syndrome (Wilms tumour, Aniridia, Genitourinary anomalies and intellectual disability), caused by a partial deletion of chromosome 11p13, which includes the PAX6 and WT1 genes, has also been reported in cases of childhood ovarian 
Table 2 Other CPS (non-sex chromosomal aneuploidy syndromes) associated with paediatric ovarian GCTs

\begin{tabular}{|c|c|c|c|}
\hline CPS & $\begin{array}{l}\text { Subtype of ovarian GCTs } \\
\text { (age of onset in years) }\end{array}$ & $\begin{array}{l}\text { Observed } \\
\text { cases }\end{array}$ & First case \\
\hline $\begin{array}{l}\text { Cowden } \\
\text { syndrome }\end{array}$ & Dysgerminoma (7) & 1 & Cho et al, $2008^{77}$ \\
\hline $\begin{array}{l}\text { Gorlin } \\
\text { syndrome }\end{array}$ & Dysgerminoma (15) & 1 & Hoorens et al, $2016^{84}$ \\
\hline $\begin{array}{l}\text { BRCA1 } \\
\text { germline } \\
\text { mutations }\end{array}$ & Dysgerminoma (16) & 1 & Werness et al, $2000^{78}$ \\
\hline $\begin{array}{l}\text { Down } \\
\text { syndrome }\end{array}$ & Dysgerminoma (11-17) & 4 & $\begin{array}{l}\text { Gesmundo et al, } 1988^{79} \\
\text { Satgé et al, 2006 } \\
\text { Hasle et al, 2000 } \\
\text { Smucker et al, 1999 }\end{array}$ \\
\hline $\begin{array}{l}\text { Noonan- } \\
\text { like with } \\
\text { CBL } \\
\text { mutation }\end{array}$ & $\begin{array}{l}\text { Mixed GCT (immature } \\
\text { teratoma, dysgerminoma } \\
\text { and YST) at } 7 \text { years, mature } \\
\text { teratoma (14) }\end{array}$ & 1 & Hanson et al, $2014^{83}$ \\
\hline
\end{tabular}

gonadoblastoma, although to a lesser extent than Frasier syndrome or DDS. ${ }^{68}$

Gonadoblastoma has been reported in 10\%-35\% of patients with Turner syndrome with Y-chromosome material (45,X0/46,XY mosaicism). ${ }^{51} 6970$ In a cohort of females with Turner syndrome, under 1\% developed gonadoblastoma (only those with Y-chromosome material). This resulted in a cumulative risk of gonadoblastoma by age 25 years of $8 \%$, which is likely an underestimate. ${ }^{71}$ Gonadoblastoma is seen in Turner syndrome and in the wide spectrum of other sex-chromosome aneuploidy syndromes associated to gonadal dysgenesis.

Following a diagnosis of an ovarian gonadoblastoma, a personal history of Wilms tumour, renal parenchymal disease, aniridia or an underlying urogenital malformation is highly suspicious for a WT1-related disorder (table 1). Given the rarity of familial WT1 disorders, family history may not be the most helpful indicator. ${ }^{72}$ Short stature or delayed puberty in a female with a gonadoblastoma should also trigger investigations for a sex-chromosome aneuploidy syndrome, specifically Turner syndrome. The latest guideline for intersex disorders recommends gonadectomy in phenotypic females with XY karyotype who have DDS and Frasier syndromes. ${ }^{7374}$ However, Ezaki and colleagues suggest that gonadectomy could be avoided in patients with Frasier syndrome type $3 .^{60}$ Gonadectomy is also recommended in Turner syndrome if Y-chromosome material is present. ${ }^{7374}$

For ovarian germ cell tumours other than gonadoblastoma, the association with CPSs is not as clear. Familial cases of ovarian germ cell tumours and familial clustering of benign teratomas and ovarian dermoid cysts have also been described, although no genes have yet been implicated. ${ }^{7576}$ Paediatric case reports of ovarian germ cell tumours in the context of various syndromes have been published (table 2). ${ }^{77-84}$ Of note, reports describing ovarian germ cell tumours in patients with ataxia-telangiectasia (A-T) have been published. ${ }^{85} 86$ A-T, caused by biallelic mutations in the ATM gene, is associated with progressive cerebellar ataxia, oculocutaneous telangiectasia, immunodeficiency and cancer risk, especially haematological malignancies. Pathogenic variants in ATM result in DNA repair defects, making it essential to identify this syndrome, as patients can develop excessive toxicity to cancer therapy.

\section{SMALL CELL CARCINOMA OF THE OVARY OF HYPERCALCAEMIC TYPE \\ General aspects}

SCCOHT is an uncommon, but well-known, ovarian neoplasm, the histogenesis of which has been unknown until recently; it is included in the category of miscellaneous ovarian neoplasms in the 2014 WHO Classification. While uncommon, SCCOHT is the most frequent undifferentiated ovarian cancer presenting in women below the age of 40 , with a mean age at diagnosis of 24 years. ${ }^{87}$ It has been reported in females as young as 14 months, ${ }^{88} 89$ but most often arises in the second or third decade of life. ${ }^{87}$ In two-thirds of cases, the patients have serum hypercalcaemia. SCCOHT is an extremely aggressive cancer, with $65 \%$ of cases recurring following primary therapy and longterm survival rates of 33\%-55\% for early stage and $0 \%-30 \%$ for advanced stage neoplasms. ${ }^{9091}$ Due to the aggressive nature of the tumour, a correct diagnosis at presentation is crucial.

\section{Key differential diagnoses}

Establishing a diagnosis of SCCOHT may be difficult, as there is a broad differential diagnosis. The differential diagnosis may include a wide range of neoplasms, including AGCT, JGCT, germ cell tumours, endometrial stromal sarcoma, malignant melanoma, primary and metastatic small cell neuroendocrine carcinoma and a variety of small round blue cell tumours, which highlight the importance of expert pathology review for accurate diagnosis (box). ${ }^{8792}$ While the tumour cells in SCCOHT usually have scant cytoplasm resulting in a small cell appearance, some cases contain tumour cells with abundant eosinophilic cytoplasm, often resulting in a large cell appearance, sometimes with a rhabdoid morphology. As discussed below, SCCOHT is caused by mutations in the chromatin remodelling gene SMARCA4. ${ }^{90}$ These mutations are accompanied by loss of expression of the SMARCA4 (BRG1) protein in 97\% of cases, and immunostaining for SMARCA4 has now been established as an extremely useful way to diagnose SCCOHT and distinguishes this entity from its mimics which almost always exhibit retention of nuclear immunoreactivity (figure 2). ${ }^{93}$

\section{Cancer predisposition syndromes}

It has recently been established that SCCOHT is a monogenic disease and caused primarily by germline and somatic deleterious mutations in the chromatin remodelling gene SMARCA4, a member of the SWI/SNF chromatin remodelling complex. ${ }^{90}$

Prior to the discovery of the association between SMARCA4 and SCCOHT, it was found that germline mutations in SMARCA4 can predispose patients to the development of rhabdoid tumours, including atypical teratoid/rhabdoid tumours, which are most often caused by mutations in another chromatin remodelling gene, SMARCB1. ${ }^{94} 95$ Germline mutations in SMARCB1 and SMARCA4 are associated with rhabdoid tumour predisposition syndrome types 1 and 2, respectively (RTPS1 and RTPS2); mutations were discovered to underlie the development of SCCOHT, and it was also recognised that these ovarian tumours are in fact morphologically very similar to rhabdoid tumours. Their similarity has led to the suggestion that SCCOHT is part of the rhabdoid tumour spectrum, and geneticists should now recognise that female carriers of pathogenic SMARCA4 mutations are at risk for both rhabdoid tumours and SCCOHT.

While RTPS2-associated SMARCA4 mutations are largely loss of function variants, a handful of missense variants have been described. ${ }^{90}$ These variants have been found to occur across the length of the gene, with no predominant hotspot regions. ${ }^{90}$ 
Missense variants in SMARCA4 and other members of the SWI/ SNF complex more often cause Coffin-Siris syndrome, a developmental disorder not associated with tumour development, rather than RTPS2. ${ }^{96}$ Additionally, one case has been reported of a patient with a de novo SMARCA4 nonsense variant and concomitant Coffin-Siris syndrome, microphthalmia and SCCOHT. ${ }^{97}$

Although few familial cases have been described, studies have shown that up to $43 \%$ of patients with SCCOHT harbor a germline mutation in SMARCA4. ${ }^{90}$ This often occurs in patients with no family history of SCCOHT or rhabdoid tumours, and in these cases, the pathogenic mutation is usually inherited from the patient's father. ${ }^{9899}$ Penetrance of these mutations is still unknown.

Given the high incidence of SMARCA4 germline mutations in patients with SCCOHT, we recommend that once the diagnosis is established, all patients should be referred to a genetics service and undergo genetic counselling. Patients diagnosed below the age of 20 years are highly likely to carry a germline mutation..$^{90}$ If a pathogenic mutation is found, all relevant relatives should undergo genetic counselling and testing for the familial variant. However, the unknown penetrance of these mutations and the young age of onset of this tumour makes it difficult to counsel mutation carriers and their families. Female carriers of truncating mutations are at risk for SCCOHT, and infant carriers of both genders may be at risk for rhabdoid tumours (table 1). As SMARCA4-mutated rhabdoid tumours have not been reported in patients older than 46 months, the development of these tumours in older carriers is unlikely. ${ }^{100}$ However, the oldest woman to date diagnosed definitively with SCCOHT (showing loss of SMARCA4 staining in her tumour) was 56 years old at diagnosis. ${ }^{90}$ Further testing of affected and unaffected family members will hopefully elucidate the true penetrance and allow carriers to be more informed when making potentially life-altering decisions.

Currently there are no established preventive recommendations for female carriers. Bilateral oophorectomy would likely be an effective preventive measure, ${ }^{101}$ but without penetrance data, determining the optimal age to consider this option is difficult. Prophylactic oophorectomy may be considered by young females known to carry a germline SMARCA4 mutation and has been performed in at least one adolescent carrier. ${ }^{99}$ The efficacy of ovarian surveillance for female carriers is still undetermined, but until data are available, ovarian imaging is a reasonable option.

Although the familial incidence of SCCOHT, and RTPS2 in general, is low, it is important to note the high fraction caused by germline SMARCA4 mutations and to recognise that even without a family history, the tumour may be hereditary if the patient has inherited a germline mutation from her father or acquired one de novo (figure 3B). Furthermore, it is important to note that infant carriers of both genders may be at risk for rhabdoid tumours in addition to SCCOHT.

\section{CONCLUSION}

Ovarian tumours in the paediatric population are not common, but in cases where they arise, consideration should be given to a possible underlying CPS, especially with a SCST. A thorough personal and family history should be collected as well as details on the tumour that may increase its likelihood of being the result of a germline mutation in a cancer predisposition gene. Although we have highlighted the most commonly known genes associated with these syndromes, novel sequencing techniques may uncover new genes and syndromes associated with uncommon ovarian tumours. Discovery of new gene-disease associations is outpacing clinical guidelines and physicians should always remain suspicious of a CPS following the diagnosis of an uncommon/rare ovarian tumour in a paediatric patient.

Acknowledgements The authors would like to thank Dr John R Priest for his assistance with this manuscript and the identification of one of the families illustrated in this review. We also thank Marie Jeanjean for her assistance with one the families presented in this review.

Contributors CG, LW and SV: implicated in all aspects of this review and cowrote the manuscript; WGMC: creation of the figures, revision of the manuscript draft: WDF: review conception and revision of manuscript draft.

Funding WDF acknowledges the funding support of the Canadian Institutes of Health Research (FDN: 148390). CG's research was generously funded by a grant from the Cedars Cancer Foundation and the Montreal Children's Hospital Foundation.

\section{Competing interests None declared.}

Provenance and peer review Commissioned; externally peer reviewed.

(c) Article author(s) (or their employer(s) unless otherwise stated in the text of the article) 2018. All rights reserved. No commercial use is permitted unless otherwise expressly granted.

\section{REFERENCES}

1 Young RH, Dickersin GR, Scully RE. Juvenile granulosa cell tumor of the ovary. A clinicopathological analysis of 125 cases. Am J Surg Pathol 1984;8:575-96.

2 Wu H, Pangas SA, Eldin KW, Patel KR, Hicks J, Dietrich JE, Venkatramani R. Juvenile Granulosa Cell Tumor of the Ovary: A Clinicopathologic Study. J Pediatr AdolesC Gynecol 2017;30:138-43.

3 Auguste A, Bessière L, Todeschini AL, Caburet S, Sarnacki S, Prat J, D'angelo E, De La Grange P, Ariste O, Lemoine F, Legois B, Sultan C, Zider A, Galmiche L, Kalfa $\mathrm{N}$, Veitia RA. Molecular analyses of juvenile granulosa cell tumors bearing AKT1 mutations provide insights into tumor biology and therapeutic leads. Hum Mol Genet 2015;24:6687-98.

4 Shah SP, Köbel M, Senz J, Morin RD, Clarke BA, Wiegand KC, Leung G, Zayed A, Mehl E, Kalloger SE, Sun M, Giuliany R, Yorida E, Jones S, Varhol R, Swenerton KD, Miller D, Clement PB, Crane C, Madore J, Provencher D, Leung P, DeFazio A, Khattra J, Turashvili G, Zhao Y, Zeng T, Glover JN, Vanderhyden B, Zhao C, Parkinson CA, Jimenez-Linan M, Bowtell DD, Mes-Masson AM, Brenton JD, Aparicio SA, Boyd N, Hirst M, Gilks CB, Marra M, Huntsman DG. Mutation of FOXL2 in granulosa-cell tumors of the ovary. N Engl J Med 2009;360:2719-29.

5 Jamieson S, Butzow R, Andersson N, Alexiadis M, Unkila-Kallio L, Heikinheimo M, Fuller PJ, Anttonen M. The FOXL2 C134W mutation is characteristic of adult granulosa cell tumors of the ovary. Mod Pathol 2010;23:1477-85.

6 Tamimi HK, Bolen JW. Enchondromatosis (Ollier's disease) and ovarian juvenile granulosa cell tumor. A case report and review of the literature. Cancer 1984;53:1605-8.

7 Burgetova A, Matejovsky Z, Zikan M, Slama J, Dundr P, Skapa P, Benkova K, Cibula $D$, Fischerova D. The association of enchondromatosis with malignant transformed chondrosarcoma and ovarian juvenile granulosa cell tumor (Ollier disease). Taiwan J Obstet Gynecol 2017;56:253-7.

8 Pansuriya TC, Kroon HM, Bovée JV. Enchondromatosis: insights on the different subtypes. Int J Clin Exp Pathol 2010;3:557-69.

9 Silve C, Jüppner H. Ollier disease. Orphanet J Rare Dis 2006;1:37.

10 Amary MF, Damato S, Halai D, Eskandarpour M, Berisha F, Bonar F, McCarthy S, Fantin VR, Straley KS, Lobo S, Aston W, Green CL, Gale RE, Tirabosco R, Futreal A, Campbell P, Presneau N, Flanagan AM. Ollier disease and Maffucci syndrome are caused by somatic mosaic mutations of IDH1 and IDH2. Nat Genet 2011;43:1262-5

11 Foulkes WD, Gore M, McCluggage WG. Rare non-epithelial ovarian neoplasms: Pathology, genetics and treatment. Gynecol Oncol 2016;142:190-8.

12 Verdegaal SH, Bovée JV, Pansuriya TC, Grimer RJ, Ozger H, Jutte PC, San Julian M, Biau DJ, van der Geest IC, Leithner A, Streitbürger A, Klenke FM, Gouin FG, Campanacci DA, Marec-Berard P, Hogendoorn PC, Brand R, Taminiau AH. Incidence, predictive factors, and prognosis of chondrosarcoma in patients with Ollier disease and Maffucci syndrome: an international multicenter study of 161 patients. Oncologist 2011;16:1771-9

13 Gell JS, Stannard MW, Ramnani DM, Bradshaw KD. Juvenile granulosa cell tumor in a 13-year-old girl with enchondromatosis (Ollier's disease): a case report. J Pediatr Adolesc Gynecol 1998;11:147-50.

14 Plon SE, Pirics ML, Nuchtern J, Hicks J, Russell H, Agrawal S, Zbuk K, Eng C, Hegde $\mathrm{M}$, Chin EL. Multiple tumors in a child with germ-line mutations in TP53 and PTEN. N Engl J Med 2008;359:537-9.

15 Schultz KA, Pacheco MC, Yang J, Williams GM, Messinger Y, Hill DA, Dehner LP, Priest JR. Ovarian sex cord-stromal tumors, pleuropulmonary blastoma and DICER1 mutations: a report from the International Pleuropulmonary Blastoma Registry. Gynecol Oncol 2011;122:246-50. 
16 Pommert L, Bradley W. Pediatric Gynecologic Cancers. Curr Oncol Rep 2017;19:44.

17 Young RH, Scully RE. Ovarian Sertoli-Leydig cell tumors. A clinicopathological analysis of 207 cases. Am J Surg Pathol 1985;9:543-69

18 Tumours of the ovary. In: Kurman R, Carcangiu ML, Herrington CS, Young RH, et al. eds. WHO Classification of Tumours of Female Reproductive Organs. Lyon: International Agency for Research on Cancer, 2014:11-86.

19 Young RH. Sex cord-stromal tumors of the ovary and testis: their similarities and differences with consideration of selected problems. Mod Pathol 2005;18:S81-98.

20 Witkowski L, Mattina J, Schönberger S, Murray MJ, Choong CS, Huntsman DG, Reis-Filho JS, McCluggage WG, Nicholson JC, Coleman N, Calaminus G, Schneider DT, Arseneau J, Stewart CJ, Foulkes WD. DICER1 hotspot mutations in non-epithelial gonadal tumours. Br J Cancer 2013;109:2744-50.

21 Heravi-Moussavi A, Anglesio MS, Cheng SW, Senz J, Yang W, Prentice L, Fejes AP, Chow C, Tone A, Kalloger SE, Hamel N, Roth A, Ha G, Wan AN, Maines-Bandiera S, Salamanca C, Pasini B, Clarke BA, Lee AF, Lee CH, Zhao C, Young RH, Aparicio SA, Sorensen PH, Woo MM, Boyd N, Jones SJ, Hirst M, Marra MA, Gilks B, Shah SP, Foulkes WD, Morin GB, Huntsman DG. Recurrent somatic DICER1 mutations in nonepithelial ovarian cancers. N Engl J Med 2012;366:234-42.

22 de Kock L, Terzic T, McCluggage WG, Stewart CJR, Shaw P, Foulkes WD, Clarke BA. DICER1 mutations are consistently present in moderately and poorly differentiated sertoli-leydig cell tumors. Am J Surg Pathol 2017;41:1178-87.

23 Witkowski L, McCluggage WG, Foulkes WD. Recently characterized molecular events in uncommon gynaecological neoplasms and their clinical importance. Histopathology 2016;69:903-13.

24 Rio Frio T, Bahubeshi A, Kanellopoulou C, Hamel N, Niedziela M, Sabbaghian N, Pouchet C, Gilbert L, O'Brien PK, Serfas K, Broderick P, Houlston RS, Lesueur F, Bonora E, Muljo S, Schimke RN, Bouron-Dal Soglio D, Arseneau J, Schultz KA, Priest JR, Nguyen VH, Harach HR, Livingston DM, Foulkes WD, Tischkowitz M. DICER1 mutations in familial multinodular goiter with and without ovarian Sertoli-Leydig cell tumors. JAMA 2011;305:68-77.

25 Schultz KAP, Rednam SP, Kamihara J, Doros L, Achatz MI, Wasserman JD, Diller LR, Brugières L, Druker H, Schneider KA, McGee RB, Foulkes WD. PTEN, DICER1, $\mathrm{FH}$, and their associated tumor susceptibility syndromes: clinical features, genetics, and surveillance recommendations in childhood. Clin Cancer Res 2017;23:e76-82

26 Howell L, Bader A, Mullassery D, Losty P, Auth M, Kokai G. Sertoli Leydig cell ovarian tumour and gastric polyps as presenting features of Peutz-Jeghers syndrome. Pediatr Blood Cancer 2010;55:206-7.

27 Ravishankar S, Mangray S, Kurkchubasche A, Yakirevich E, Young RH. Unusual sertoli cell tumor associated with sex cord tumor with annular tubules in peutz-jeghers syndrome: report of a case and review of the literature on ovarian tumors in peutzjeghers syndrome. Int J Surg Pathol 2016;24:269-73.

28 Scully RE. Sex cord tumor with annular tubules a distinctive ovarian tumor of the Peutz-Jeghers syndrome. Cancer 1970;25:1107-21.

29 Brown J, Sood AK, Deavers MT, Milojevic L, Gershenson DM. Patterns of metastasis in sex cord-stromal tumors of the ovary: can routine staging lymphadenectomy be omitted? Gynecol Oncol 2009;113:86-90.

30 Qian Q, You Y, Yang J, Cao D, Zhu Z, Wu M, Chen J, Lang J, Shen K. Management and prognosis of patients with ovarian sex cord tumor with annular tubules: a retrospective study. BMC Cancer 2015:15:270.

31 Young RH, Welch WR, Richard Dickersin G, Scully RE, Alam Leicestershire SZ, Alwasiak J, Arden S, Astacio San Salvador J, Salvador E Beck Anchorage AK PC, Berkowitz SB, Castle S, Lattin J, Chung Taegu CH Cun-ningham Birmingham J AL, Dahlin DC, Dickson Utica WB, Finley J, Gyori Chicago G, Hagley K, Indies W, Hartney Chicago J, Hertig AT, Hugh-esdon P, Humphries Augusta A, Idelson M, Kalengayi PM R. Ovarian sex cord tumor with annular tubules. Cancer 1982:50:1384-402.

32 Hinds R, Philp C, Hyer W, Fell JM. Complications of childhood Peutz-Jeghers syndrome: implications for pediatric screening. J Pediatr Gastroenterol Nutr 2004;39:219-20.

33 Syngal S, Brand RE, Church JM, Giardiello FM, Hampel HL, Burt RW. ACG clinical guideline: genetic testing and management of hereditary gastrointestinal cancer syndromes. Am J Gastroenterol 2015;110:223-62.

34 van Lier MG, Wagner A, Mathus-Vliegen EM, Kuipers EJ, Steyerberg EW, van Leerdam ME. High cancer risk in Peutz-Jeghers syndrome: a systematic review and surveillance recommendations. Am J Gastroenterol 2010;105:1258-64.

35 Schreibman IR, Baker M, Amos C, McGarrity TJ. The hamartomatous polyposis syndromes: a clinical and molecular review. Am J Gastroenterol 2005;100:476-90.

36 Aretz S, Stienen D, Uhlhaas S, Loff S, Back W, Pagenstecher C, McLeod DR, Graham GE, Mangold E, Santer R, Propping P, Friedl W. High proportion of large genomic STK11 deletions in Peutz-Jeghers syndrome. Hum Mutat 2005;26:513-9.

37 Connolly DC, Katabuchi H, Cliby WA, Cho KR. Somatic Mutations in the STK11/ LKB1 Gene Are Uncommon in Rare Gynecological Tumor Types Associated with Peutz-Jegher' s Syndrome. Cancer 2000;156:339-45.

38 Lim W, Olschwang S, Keller JJ, Westerman AM, Menko FH, Boardman LA, Scott RJ, Trimbath J, Giardiello FM, Gruber SB, Gille JJ, Offerhaus GJ, de Rooij FW, Wilson $J H$, Spigelman AD, Phillips RK, Houlston RS. Relative frequency and morphology of cancers in STK11 mutation carriers. Gastroenterology 2004;126:1788-94.
39 Amos Cl, Keitheri-Cheteri MB, Sabripour M, Wei C, McGarrity TJ, Seldin MF, Nations L, Lynch PM, Fidder HH, Friedman E, Frazier ML. Genotype-phenotype correlations in Peutz-Jeghers syndrome. J Med Genet 2004;41:327-33.

40 Salloch H, Reinacher-Schick A, Schulmann K, Pox C, Willert J, Tannapfel A, Heringlake S, Goecke TO, Aretz S, Stemmler S, Schmiegel W. Truncating mutations in PeutzJeghers syndrome are associated with more polyps, surgical interventions and cancers. Int J Colorectal Dis 2010;25:97-107.

41 Hearle N, Schumacher V, Menko FH, Olschwang S, Boardman LA, Gille JJ, Keller JJ, Westerman AM, Scott RJ, Lim W, Trimbath JD, Giardiello FM, Gruber SB, Offerhaus GJ de Rooij FW, Wilson JH, Hansmann A, Möslein G, Royer-Pokora B, Vogel T, Phillips RK, Spigelman AD, Houlston RS. Frequency and spectrum of cancers in the Peutz-Jeghers syndrome. Clin Cancer Res 2006;12:3209-15.

42 Giardiello FM, Brensinger JD, Tersmette AC, Goodman SN, Petersen GM, Booker SV, Cruz-Correa M, Offerhaus JA. Very high risk of cancer in familial Peutz-Jeghers syndrome. Gastroenterology 2000;119:1447-53.

43 Achatz MI, Porter CC, Brugières L, Druker H, Frebourg T, Foulkes WD, Kratz CP, Kuiper RP, Hansford JR, Hernandez HS, Nathanson KL, Kohlmann WK, Doros L, Onel K, Schneider KW, Scollon SR, Tabori U, Tomlinson GE, Evans DGR, Plon SE. Cancer Screening Recommendations and Clinical Management of Inherited Gastrointestinal Cancer Syndromes in Childhood. Clin Cancer Res 2017;23:e107-14.

44 Oliva E, Alvarez T, Young RH. Sertoli cell tumors of the ovary: a clinicopathologic and immunohistochemical study of 54 cases. Am J Surg Pathol 2005;29:143-56.

45 Tavassoli FA, Norris HJ. Sertoli tumors of the ovary. A clinicopathologic study of 28 cases with ultrastructural observations. Cancer 1980:46:2281-97.

46 Ferry JA, Young RH, Engel G, Scully RE. Oxyphilic Sertoli cell tumor of the ovary: a report of three cases, two in patients with the Peutz-Jeghers syndrome. Int I Gynecol Pathol 1994;13:259-66

47 Massa G, Roggen N, Renard M, Gille JJ. Germline mutation in the STK11 gene in a girl with an ovarian Sertoli cell tumour. Eur J Pediatr 2007;166:1083-5.

48 Young S, Gooneratne S, Straus FH, Zeller WP, Bulun SE, Rosenthal IM. Feminizing Sertoli cell tumors in boys with Peutz-Jeghers syndrome. Am J Surg Pathol 1995:19:50-8.

49 Poynter JN, Amatruda JF, Ross JA. Trends in incidence and survival of pediatric and adolescent patients with germ cell tumors in the United States, 1975 to 2006 Cancer 2010;116:4882-91.

50 Brant WO, Rajimwale A, Lovell MA, Travers SH, Furness PD, Sorensen M, Oottamasathien S, Gonadoblastoma KMA, Syndrome T. J Urol 2006;175:1858-60.

51 Cools M, Stoop H, Kersemaekers AM, Drop SL, Wolffenbuttel KP, Bourguignon JP, Slowikowska-Hilczer J, Kula K, Faradz SM, Oosterhuis JW, Looijenga LH. Gonadoblastoma arising in undifferentiated gonadal tissue within dysgenetic gonads. J Clin Endocrinol Metab 2006;91:2404-13.

52 De Backer A, Madern GC, Oosterhuis JW, Hakvoort-Cammel FG, Hazebroek FW. Ovarian germ cell tumors in children: a clinical study of 66 patients. Pediatr Blood Cancer 2006:46:459-64

53 Kurman RJ, Norris HJ. Embryonal carcinoma of the ovary: a clinicopathologic entity distinct from endodermal sinus tumor resembling embryonal carcinoma of the adult testis. Cancer 1976;38:2420-33.

54 Murugaesu N, Schmid P, Dancey G, Agarwal R, Holden L, McNeish I, Savage PM, Newlands ES, Rustin GJ, Seckl MJ. Malignant ovarian germ cell tumors: identification of novel prognostic markers and long-term outcome after multimodality treatment. J Clin Oncol 2006;24:4862-6.

55 Lai CH, Chang TC, Hsueh S, Wu TI, Chao A, Chou HH, Wang PN. Outcome and prognostic factors in ovarian germ cell malignancies. Gynecol Oncol 2005;96:784-91.

56 Mueller RF. The Denys-Drash syndrome. J Med Genet 1994;31:471-7.

57 Kreidberg JA, Sariola H, Loring JM, Maeda M, Pelletier J, Housman D, Jaenisch R. WT-1 is required for early kidney development. Cell 1993:74:679-91.

58 Call KM, Glaser T, Ito CY, Buckler AJ, Pelletier J, Haber DA, Rose EA, Kral A, Yeger $H_{\text {, }}$ Lewis WH. Isolation and characterization of a zinc finger polypeptide gene at the human chromosome 11 Wilms' tumor locus. Cell 1990;60:509-20.

59 Barbaux S, Niaudet P, Gubler MC, Grünfeld JP, Jaubert F, Kuttenn F, Fékété CN, Souleyreau-Therville N, Thibaud E, Fellous M, McElreavey K. Donor splice-site mutations in WT1 are responsible for Frasier syndrome. Nat Genet 1997;17:467-70.

60 Ezaki J, Hashimoto K, Asano T, Kanda S, Akioka Y, Hattori M, Yamamoto T, Shibata N. Gonadal tumor in Frasier syndrome: a review and classification. Cancer Prev Res 2015:8:271-6

61 Niaudet P, Gubler MC. WT1 and glomerular diseases. Pediatr Nephrol 2006;21:1653-60.

62 Sinha A, Sharma S, Gulati A, Sharma A, Agarwala S, Hari P, Bagga A. Frasier syndrome: early gonadoblastoma and cyclosporine responsiveness. Pediatr Nephrol 2010;25:2171-4

63 Joki-Erkkilä MM, Karikoski R, Rantala I, Lenko HL, Visakorpi T, Heinonen PK. Gonadoblastoma and dysgerminoma associated with XY gonadal dysgenesis in an adolescent with chronic renal failure: a case of Frasier syndrome. J Pediatr Adolesc Gynecol 2002;15:145-9.

64 Guaragna MS, Lutaif AC, Bittencourt VB, Piveta CS, Soardi FC, Castro LC, Belangero VM, Maciel-Guerra AT, Guerra-Junior G, Mello MP. Frasier syndrome: four new cases with unusual presentations. Arq Bras Endocrinol Metabol 2012;56:525-32. 
65 Pelletier J, Bruening W, Kashtan CE, Mauer SM, Manivel JC, Striegel JE, Houghton DC, Junien C, Habib R, Fouser L. Germline mutations in the Wilms' tumor suppressor gene are associated with abnormal urogenital development in Denys-Drash syndrome. Cell 1991;67:437-47.

66 Little M, Wells C. A clinical overview of WT1 gene mutations. Hum Mutat 1997:9:209-25.

67 Patel PR, Pappas J, Arva NC, Franklin B, Brar PC. Early presentation of bilateral gonadoblastomas in a Denys-Drash syndrome patient: a cautionary tale for prophylactic gonadectomy. J Pediatr Endocrinol Metab 2013;26:971-4.

68 Andersen SR, Geertinger P, Larsen HW, Mikkelsen M, Parving A, Vestermark S, Warburg M. Aniridia, cataract and gonadoblastoma in a mentally retarded girl with deletion of chromosome II. A clinicopathological case report. Ophthalmologica 1977:176:171-7.

69 Zelaya G, López Marti JM, Marino R, Garcia de Dávila MT, Gallego MS Gonadoblastoma in patients with Ullrich-Turner syndrome. Pediatr Dev Pathol 2015; 18:117-21

70 Gravholt CH, Fedder J, Naeraa RW, Müller J. Occurrence of gonadoblastoma in females with Turner syndrome and $Y$ chromosome material: a population study. J Clin Endocrinol Metab 2000;85:3199-202.

71 Schoemaker MJ, Swerdlow AJ, Higgins CD, Wright AF, Jacobs PA; Cancer incidence in women with Turner syndrome in Great Britain: a national cohort study. Lancet Oncol 2008;9:239-46.

72 Kaneko Y, Okita H, Haruta M, Arai Y, Oue T, Tanaka Y, Horie H, Hinotsu S, Koshinaga T, Yoneda A, Ohtsuka Y, Taguchi T, Fukuzawa M. A high incidence of WT1 abnormality in bilateral Wilms tumours in Japan, and the penetrance rates in children with WT1 germline mutation. Br J Cancer 2015;112:1121-33.

73 Hughes IA, Houk C, Ahmed SF, Lee PA. Consensus statement on management of intersex disorders. J Pediatr Uro/ 2006:2:148-62.

74 McCann-Crosby B, Mansouri R, Dietrich JE, McCullough LB, Sutton VR, Austin EG, Schlomer B, Roth DR, Karaviti L, Gunn S, Hicks MJ, Macias CG. State of the art review in gonadal dysgenesis: challenges in diagnosis and management. Int J Pediatr Endocrinol 2014:2014:4

75 Giambartolomei C, Mueller CM, Greene MH, Korde LA. A mini-review of familial ovarian germ cell tumors: an additional manifestation of the familial testicular germ cell tumor syndrome. Cancer Epidemiol 2009:33:31-6.

76 Caspi B, Kassif E, Appelman Z, Hagay Z. Hereditary ovarian dermoid cysts-a brief clinical case report. Acta Obstet Gynecol Scand 2000;79:796-7.

77 Cho MY, Kim HS, Eng C, Kim DS, Kang SJ, Eom M, Yi SY, Bronner MP. First report of ovarian dysgerminoma in Cowden syndrome with germline PTEN mutation and PTEN-related 10q loss of tumor heterozygosity. Am J Surg Pathol 2008;32:1258-64.

78 Werness BA, Ramus SJ, Whittemore AS, Garlinghouse-Jones K, Oakley-Girvan I, DiCioccio RA, Tsukada Y, Ponder BA, Piver MS. Primary ovarian dysgerminoma in a patient with a germline BRCA1 mutation. Int J Gynecol Pathol 2000;19:390-4.

79 Gesmundo R, Bevilacqua A, Gandini R, Maiullari E, Moro G. A case of ovarian dysgerminoma in Down's syndrome. Minerva Ginecol 1988;40:277-80.

80 Satgé $\mathrm{D}$, Honoré L, Sasco AJ, Vekemans M, Chompret A, Réthoré MO. An ovarian dysgerminoma in Down syndrome. Hypothesis about the association. Int J Gynecol Cancer 2006:16:375-9.

81 Hasle H, Clemmensen IH, Mikkelsen M. Risks of leukaemia and solid tumours in individuals with Down's syndrome. Lancet 2000;355:165-9.

82 Smucker JD, Roth LM, Sutton GP, Hurteau JA. Trisomy 21 associated with ovarian dysgerminoma. Gynecol Oncol 1999;74:512-4.

83 Hanson HL, Wilson MJ, Short JP, Chioza BA, Crosby AH, Nash RM, Marks KJ, Mansour S. Germline CBL mutation associated with a noonan-like syndrome with primary lymphedema and teratoma associated with acquired uniparental isodisomy of chromosome 11q23. Am J Med Genet A 2014;164A:1003-9.

84 Hoorens I, van de Kerckhove MPB. Nevoid Basal Cell Carcinoma Syndrome and dysgerminoma: an incidental association ? J Eur Acad Dermatology Venereol 2016:30:e53-5.

85 Dunn HG, Meuwissen H, Livingstone CS, Ataxia-Telangiectasia PKKCan Med Assoc J 1964:91:1106-18.

86 Koksal Y, Caliskan U, Ucar C, Yurtcu M, Artac H, Ilerisoy-Yakut Z, Reisli I. Dysgerminoma in a child with ataxia-telangiectasia. Pediatr Hematol 2007:24:431-6.
87 Young RH, Oliva E, Scully RE. Small cell carcinoma of the ovary, hypercalcemic type. A clinicopathological analysis of 150 cases. Am J Surg Pathol 1994;18:1102-16.

88 Harrison ML, Hoskins P, du Bois A, Quinn M, Rustin GJ, Ledermann JA, Baron-Hay S, Friedlander ML. Small cell of the ovary, hypercalcemic type - analysis of combined experience and recommendation for management. A GCIG study. Gynecol Oncol 2006:100:233-8.

89 Florell SR, Bruggers CS, Matlak M, Young RH, Lowichik A. Ovarian small cell carcinoma of the hypercalcemic type in a 14 month old: the youngest reported case. Med Pediatr Oncol 1999:32:304-7.

90 Witkowski L, Goudie C, Ramos P, Boshari T, Brunet JS, Karnezis AN, Longy M, Knost JA, Saloustros E, McCluggage WG, Stewart CJR, Hendricks WPD, Cunliffe $H$, Huntsman DG, Pautier P, Levine DA, Trent JM, Berchuck A, Hasselblatt M, Foulkes WD. The influence of clinical and genetic factors on patient outcome in small cel carcinoma of the ovary, hypercalcemic type. Gynecol Oncol 2016;141:454-60.

91 Estel R, Hackethal A, Kalder M, Münstedt K. Small cell carcinoma of the ovary of the hypercalcaemic type: an analysis of clinical and prognostic aspects of a rare disease on the basis of cases published in the literature. Arch Gynecol Obstet 2011:284:1277-82.

92 McCluggage WG, Oliva E, Connolly LE, McBride HA, Young RH. An immunohistochemical analysis of ovarian small cell carcinoma of hypercalcemic type. Int J Gynecol Pathol 2004;23:330-6.

93 Witkowski L, Goudie C, Foulkes WD, McCluggage WG. Small-cell carcinoma of the ovary of hypercalcemic type (Malignant Rhabdoid Tumor of the Ovary): a review with recent developments on pathogenesis. Surg Pathol Clin 2016;9:215-26.

94 Schneppenheim R, Frühwald MC, Gesk S, Hasselblatt M, Jeibmann A, Kordes U, Kreuz M, Leuschner I, Martin Subero JI, Obser T, Oyen F, Vater I, Siebert R. Germline nonsense mutation and somatic inactivation of SMARCA4/BRG1 in a family with rhabdoid tumor predisposition syndrome. Am J Hum Genet 2010;86:279-84.

95 Hasselblatt M, Gesk S, Oyen F, Rossi S, Viscardi E, Giangaspero F, Giannini C, Judkins AR, Frühwald MC, Obser T, Schneppenheim R, Siebert R, Paulus W. Nonsense mutation and inactivation of SMARCA4 (BRG1) in an atypical teratoid/ rhabdoid tumor showing retained SMARCB1 (INI1) expression. Am J Surg Pathol 2011;35:933-5

96 Kosho T, Miyake N, Carey JC. Coffin-Siris syndrome and related disorders involving components of the BAF (mSWI/SNF) complex: historical review and recent advances using next generation sequencing. Am J Med Genet C Semin Med Genet 2014; 166C:241-51.

97 Errichiello E, Mustafa N, Vetro A, Notarangelo LD, de Jonge $H$, Rinaldi B, Vergani $D$, Giglio SR, Morbini P, Zuffardi O. SMARCA4 inactivating mutations cause concomitant Coffin-Siris syndrome, microphthalmia and small-cell carcinoma of the ovary hypercalcaemic type. J Pathol 2017;243:9-15

98 Witkowski L, Carrot-Zhang J, Albrecht S, Fahiminiya S, Hamel N, Tomiak E, Grynspan D, Saloustros E, Nadaf J, Rivera B, Gilpin C, Castellsagué E, Silva-Smith R, Plourde F, Wu M, Saskin A, Arseneault M, Karabakhtsian RG, Reilly EA, Ueland FR, Margiolaki A, Pavlakis K, Castellino SM, Lamovec J, Mackay HJ, Roth LM, Ulbright TM, Bender TA, Georgoulias V, Longy M, Berchuck A, Tischkowitz M, Nagel I, Siebert R, Stewart CJ, Arseneau J, McCluggage WG, Clarke BA, Riazalhosseini Y, Hasselblatt M, Majewski J, Foulkes WD. Germline and somatic SMARCA4 mutations characterize small cell carcinoma of the ovary, hypercalcemic type. Nat Genet 2014:46:438-43.

99 Witkowski L, Donini N, Byler-Dann R, Knost JA, Albrecht S, Berchuck A, McCluggage WG, Hasselblatt M, Foulkes WD. The hereditary nature of small cell carcinoma of the ovary, hypercalcemic type: two new familial cases. Fam Cancer 2017;16:395-9.

100 Hasselblatt M, Nagel I, Oyen F, Bartelheim K, Russell RB, Schüller U, Junckerstorff R, Rosenblum M, Alassiri AH, Rossi S, Schmid I, Gottardo NG, Toledano H, Viscardi E, Balbin M, Witkowski L, Lu Q, Betts MJ, Foulkes WD, Siebert R, Frühwald MC, Schneppenheim R. SMARCA4-mutated atypical teratoid/rhabdoid tumors are associated with inherited germline alterations and poor prognosis. Acta Neuropathol 2014;128:453-6.

101 Berchuck A, Witkowski L, Hasselblatt M, Foulkes WD. Prophylactic oophorectomy for hereditary small cell carcinoma of the ovary, hypercalcemic type. Gynecol Oncol Rep 2015:12:20-2. 